\title{
Item Songs of Bollywood: The Politics of Gender and Identity and Sexual Objectification
}

\author{
Defency J Purohit
}

Assistant Professor, Career Development Cell (PIET), Parul University, Limda - Waghodia, Vadodara, Gujarat, India

\begin{abstract}
This paper aims to analyse the gender politics in the item songs by drawing parallels between the content of the item songs and theory of sexual objectification using psychoanalysis and social and behavioural theories. It tries to evaluate the role of media, patriarchy and psychology in conforming and forming gender roles and sexual objectification. It also tries to bring to notice dire consequences of sexual objectification.
\end{abstract}

Keywords-Media, Gender roles, Item songs, Patriarchy, Language, Visual Pleasure, Sexual objectification.

\section{INTRODUCTION}

Since the inception of Bollywood in $20^{\text {th }}$ century, songs have been an integral part of Hindi films, communicating the story and aesthetics of romance in the films. Patriarchy has always been influential in framing gender roles in Bollywood films and songs. The Woman is reduced to marginalised roles; of the love interest of the hero, or as decorative objects to glamorise the hero-centric setup. It does not acknowledge or communicate diverse roles played by women in Indian society. The portrayal of women is limited to submissive, virtuous, conservative, and self-sacrificing or of bold, glamorous, sensuous and bawdy like; both the roles only in relation with the male. These depictions mirror the values dominant in society, simultaneously reinforcing these images of women into the target audience, play a vital role in socializing the coming generations. Song-dance being a characteristic feature of Hindi films, it is disseminated across all the classes and celebrated across the country. Out of all the genres of song and music, a fusion of rock with traditional Hindi music and high music have been of great prominence in the popular contemporary songs, especially item songs or the peppy dance numbers featured in the film. Although a small shift can be marked in the roles played by women in contemporary films, the item songs, that has become an inseparable part of present Bollywood films, continue to objectify women in every possible manner.

\section{HISTORY}

Item songs have been part of the Hindi films since $90 \mathrm{~s}$, but it's roots can be traced back to the late $18^{\text {th }}$ century Mughal empire and north Indian culture. It belongs to the class of courtesans who were trained in dance and singing, who entertained the elite, and would also provide sexual services, depending on various factors.
After their decadence, due to anti nautch movement, they took refuge into Hindi cinema and a large number also managed to the new film industry. The status of nautch girl, which is denigrating, seems to be associated with the item songs with the infusion of the ethos of the kotha system in Bollywood, since the outset of the Hindi film industry, and led to the use and display of the Madonna and whore complex (coined by Sigmund Freud) into the narrow portrayal of the women into two types, as discussed earlier in this article. It served as one of the devices to sexual objectification of women in dance numbers. Maar daala (Devdas -2002) depicts the courtesan culture.

\section{ANALYSIS}

What is problematic about these portraiture of women, is the fact that they are formed conforming to the patriarchal norms, as to keep the power structure in order. An item song is patriarchal perception of woman, where her role is reduced to attracting the audience, given the fact that, it catalyses box office collection. They are not shown to be productive, or as equal contributors to the economy or society.

The underlying patriarchal normative ideology at play in item songs can be analysed on several fronts, the psychological being the most important. Women, in phallocentric (male-dominated) society, is made to realize the lack of phallus, as symbolic to inferior or the castrated. Her identity or existence can therefore, only be in relation to the phallus or castration and not beyond that, making her identity totally in relation to the males in her life. The symbolic being deeply rooted in the unconscious is difficult to be articulated, as being coded in the patriarchal order. The item songs have skilfully manipulated visual pleasure, offering a glimmer of satisfaction to the memory 
of potential lack in the unconscious through the erotic, that is coded into the language of dominant patriarchal order.

Lacan's concept of mirror image is crucial in understanding the recognition of the self and forming of the ego or identity. The item songs, due to the intensity of expression, becomes a mode of fascination resulting in temporary loss of the ego, simultaneously reinforcing the ego that identifies with the image presented on screen. Thus the ego recognizes this image as an epitome of perfection and more importantly complete. As a result what happens is misrecognition of the self and the other. This is what happens in the glamorous expression of item songs.

\section{The Visuals in Item songs:}

The viewers are completely detached to the camera, and the real relation of characters with each other with the intensity of music and ultra - glamorous set up. The set up being hero-centric, what occurs in item songs is only sexual objectification and depreciation of women. Women are presented as subject to male gaze and desires, given the fact that the gaze of the media is essentially masculine. And since the gender equality does not prevail, pertaining to patriarchal dogmas, the masculine is always demanding and ensuring control over woman's sexuality and propagating it into society. Though prejudiced, there seems to be a strong social acceptance of sexual objetification, as these songs hit the top list of chartbusters and various other popular music platforms. A few contemporary songs can be analysed to substantiate the arguably true. The songs have been chosen on the basis of their popularity on Youtube.

\section{Laila (Shoot out at Wadala - 2013)}

Laila was instantly and extremely popular among the masses. It features Sunny Leone as a nautch girl, dancing to the rouges around her, who too partake in the dance. The song is set in a cathouse, giving a glimpse of bright and dim lights. The song depicts sunny Leone raunchily caressing her revealed body, with a sense of inviting the males around her for sexual gratification. The males in the song can be seen trying to grope, touching her inappropriately, to gain sensuous pleasure.

\section{Kamariya ( Stree-2018)}

The song features Nora Fatehi, the current popularly celebrated dancer. She is exhibited dancing between a bunch of men, who are shown to be totally in the awe of her sensuous body, the waist being the at the centre of appeal, as suggested by the title of the song. The camera focuses mainly on the close ups of her cleavage, midriff, waist and hips, and lustful gestures of the men around her suggestive of the enjoyment in the sight of her body parts by the males.

\section{Chamma Chamma (Fraud Saiyan-2019)}

The song is described as "ultra-modern song showcasing breath taking dance moves of Elli AvRam" in the description of Youtube. It features Elli AvRam. It depicts a skinny girl in skimpy outfits, performing seductive moves. She is shown to be lustful, showing sexual readiness. Throughout the song the cameras mostly gives a sensuous view of the revealed body parts repeatedly and her luscious gestures.

These are only a few songs from the many of such item songs. The audience delight in the objectified exhibition of the women, in item songs by associating it with false modernity, and at the same time disapproves of such expression of sexuality of woman, wherein it deliberately overlooks, it being coded in the dominant patriarchal order.

\section{The Language in Item songs:}

Semiotically, the women has always been the signifier and not the maker of the meaning. Language here, becomes a medium of expression of the libido of the males, articulating male desires, whereas the woman is still tied to the same place as the bearer of the meaning. Language of item songs used for women is of demeaning and sexist nature. It pompously portrays women as objects out there to fulfill male desires. Here are a few examples to consolidate the argumemt.

Mungda (Total Dhamaal - 2019)

"Mungda...mai gud ki dali

Female: Boy!... I am sweet as jaggery

Mangta hai toh aaja rasiya..

If you want some nectar, come to me right now

Le baiyaan tham gori gulabi

Catch hold of my arms, they are white and rosy

Male: zara tera nasha mai chakh lu aaya mai teri gali.

Let me get little taste of your intoxication. I am coming to your street."1

The woman here is portrayed as an intoxicating beauty, as sweet as a piece of jaggery, who invites the males to catch hold of her and taste the nectar of her intoxicating body, which is readily accepted by the males.

Pinky ( Zanjeer- 2013)

Female:Cash chahiye mujhe cash chahiye

"I just want cash

Paisa phek tamasha deks 
Throw money and watch the show

Pinky hai paise walo ki

Pinky belongs to those who have money

World famous hai mera glamour bada

My glamour is world famous

Aaye cable connection ke jaisa maza

I'll be so near and clear to you like a cable T.V. connection"2

The song depicts cash, as a major concern for women, she can be agreed to entertain the males if given money...her glamour compared to the women shown on television, shows the idealistic fantasies of the males, which should be fulfilled by the females.

\section{Halkat jawani (Heroine-2012)}

"Aa chhoron ki niyat halal kare aah

It kills the noble intensions of the guys

Arrey basti me daily bawaal kare

It creates an uproar in the coloney everyday

Item banake rakh le

Make me your item (mistress) and keep me

Chakna banake chakh le

Make me a snack and taste me

Aankho ko kyu seke

Why are you warming your eyes

Haathon se kar manmaani

Have your wish fulfilled with your hands

Night ki naughty kahaani

It's the naughty story of the night

Ye halkat jawani

This careless prime youth." ${ }^{3}$

What is intriguing about this song is, it's from the film Heroine, depicting negatives of women in popular culture of cinema. It depicts the women and her sexuality as responsible for ruining the nobility in men and society. What we see is self-objectification, or a need of phallus for complete identity.

\section{Effects of sexual objectification:}

According to social and cultivation theory, human beings tend to cultivate social patterns very easily. A lot of males and females idealise these portrayals seeking cultural validation and submitting to the pressure of meeting up the new set of standards. The direct effect of sexual objectification can lead to constant consciousness of the self in terms of physical appearance, clothing, checking oneself in the mirror frequently. The indirect effect of sexual objectification can lead to internalization of such experiences leading to the anxiety of being physically evaluated by the males and other women. The fear of being unappreciated, would lead to extreme anxiety to be a part of the popular crowd. Extreme anxiety and fear of not being able to conform to the norms can result into eating disorders, fear of body shaming, making oneself unaware of natural body functions such as hunger, stomach contractions; thus creating confusion in brain. It overshadows the intellect and other motivational opportunities of progress, leading to depression and disruption of regular body functions.

\section{CONCLUSION}

Media plays a significant role in constructing ideologies and sociocultural context that objectify women. The hold of these songs over the masses can be gauged from the evident popularity of these songs. People: be it males or females, especially the young, easily identify with these media images, making it into trends. It posits a threat to the society by normalizing disrespectful and sexist behaviour towards women, as offensive language and inappropriate touch and gaze of the males is shown with a lot of ease and acceptance. It becomes a matter of concern as it propagates gender roles into society. There needs to be a check on the content, concerning the underlying force of forming identity without even realizing it, adhering to the formations and mechanisms of ego and libido at play.

\section{REFERENCES}

[1] Juneja, Kunwar. BollyNook, Home Page, 9 December 2019, < https://www.bollynook.com/en/lyrics/21844/mungda/>

[2] Ahmed, Shabbir. Ali, Ashraf. BollyNook, Home Page, 9 December 2019 , <https://www.bollynook.com/en/lyrics/12072/pinky/>

[3] Bhattacharya, Amitabh. BollyNook, Home Page, 9 December 2019, <https://www.bollynook.com/en/lyrics/6575/halkatjawani/>

[4] Fredrickson, Barbara and Roberts, Tomi - Ann. (1997: 1 - 39) "Objectification Theory: Toward Understanding Women's Lived Experiences and Mental Health Risks." Psychology of Women Quarterly, 21, printed in the USA.

[5] Lacan, J. (2006: 93 - 100.) " The Mirror Stage as Formative of the I Function." Ecrits: The First Complete Edition in English, New York. W.W Norton \& Company.

[6] Mulvey , L. (1991:833-44.) "Visual Pleasure and Narrative Cinema." Film Theory and Criticism: Introductory Readings. Eds. Leo Braudy and Marshall Cohen. New York: Oxford Up.

[7] Bose, Mihir (2006). "Bollywood: A History."

[8] Shrum, L.(2017). Cultivation Theory: Effects and Uderlying Processes. 10.1002/9781118783764.wbieme0040

[9] Daniyal, Shoaib. "From Tawaif To Item Girl.", Home Page, 9 December 2019, <http://www.motherlandmagazine.com/from-tawaif-to-itemgirl/> 